\title{
Radar Measurements of Ice Sheet Thickness of Outlet Glaciers in Greenland
}

\author{
D. Braaten ${ }^{+}$and S. Gogineni \\ Radar Systems and Remote Sensing Laboratory and ${ }^{+}$Dept. Physics and Astronomy \\ The University of Kansas \\ Lawrence, KS 66045 U.S.A.
}

\begin{abstract}
We have conducted airborne measurements over the Greenland ice sheet from the NASA P-3B aircraft using a 150MHz coherent radar depth sounder to obtain extensive ice sheet thickness measurements. Simultaneous measurements of ice sheet elevation were also made using a laser altimeter. In outlet glacier areas along the ice sheet margin, the ice surface is characterized by a very rough, crevassed surface near the calving front. The rough ice surface generates signal clutter, which can mask the bottom echo. We are developing a technique to remove the surface clutter component from the signal to reveal the bottom echo, providing a complete ice thickness survey to the calving front of outlet glaciers. This technique makes use of a dense array of ice surface elevation measurements provided by the laser altimeter to characterize surface roughness. Surface roughness parameters are then used in a backscatter model to characterize the clutter waveform, which can be subsequently removed from the radar signal.
\end{abstract}

\section{INTRODUCTION}

As part of a multifaceted NASA research initiative to assess the mass balance of the Greenland ice sheet, the University of Kansas has been operating an airborne radio echo sounder to obtain ice thickness measurements along the flight lines flown by the NASA P-3B since 1993. A laser altimeter provides simultaneous high-resolution surface elevation measurements. Both the ice thickness and elevation data are tagged with precise GPS-derived position information, providing far superior geolocation of measurements in comparison to previous surveys [1]. Based on intercomparisons with ice core locations at both high elevation interior Greenland sites, and sites in the vicinity of Greenland outlet glaciers, the uncertainty of the radar ice thickness measurements are $\pm 10 \mathrm{~m}$ [2]. The uncertainty of the laser altimeter ice surface elevation measurements is given to be less than $\pm 0.1 \mathrm{~m} \mathrm{[3]}$.

Net ice sheet mass balance and glacier flow characteristics are intrinsically related to ice sheet thickness. The downslope gravitational driving stress at the bed, for instance, is directly proportional to the product of the ice thickness and the surface slope. In simple flow models, the surface velocity is proportional to the product of the fourth power of the ice thickness and the third power of the surface slope, and the volume flux is proportional to the product of the fifth power of the ice thickness and the third power of the surface slope [4]. Clearly, ice thickness is a critical and sensitive boundary condition required to model glacier dynamics, where small ice thickness errors can result in large errors in the predicted ice sheet behavior.

Ice sheet elevation measurements in several outlet glacier areas along the margin of Greenland have shown that the ice sheet has thinned significantly over a period of five years [5]. Outlet glaciers play a major role in ice discharge, accounting for about half of the total mass loss from the ice sheet [6], so understanding this thinning in the context of a warming climate is a high priority. To accomplish this, numerical models of glacier dynamics incorporating accurate ice thickness measurements are required to model the ice discharge flux. However, the nature of many Greenland outlet glacier areas make it difficult to obtain airborne radar ice thickness measurements due to high signal absorption caused by relatively warm ice conditions, signal clutter caused by rough, heavily crevassed ice surfaces, and the typically narrow terrain which confines many outlet glaciers.

The airborne radio echo sounder operated by the University of Kansas over Greenland is a low-power 150-MHz coherent radar with a digital signal processing system using 12-bit A/D converters and high-speed field-programmable gate arrays. The digital system is capable of collecting data with only 32 presummed coherent returns at a PRF of $9.2 \mathrm{kHz}$. It can also collect data over 2048 range bins and operate with a maximum PRF of $18.4 \mathrm{kHz}$. Normally data is collected with a radar PRF of $9.2 \mathrm{kHz}^{-}$and the integrator set to sum 256 samples coherently to reduce data volume. The aircraft is flown in terrain-following mode at an altitude of about $450 \mathrm{~m}$ above the ice surface at an airspeed of about $130 \mathrm{~m} / \mathrm{s}$. The distance traveled in the time to collect 256 samples at $9.2 \mathrm{kHz}$ PRF is about $3.6 \mathrm{~m}$. We process the data further by coherently integrating two to four samples and incoherently integrating 10-20 samples to reduce fading. The right-hand side of the radar echogram shown in figure 1 shows strong ice-bed echoes at a depth of about $1800 \mathrm{~m}$. Ice depth is determined by computing the number of range cells between the ice surface and the ice-bedrock interface, and multiplying the result by $4.494 \mathrm{~m}$.

The conventional signal processing techniques used for the majority of the Greenland ice sheet are generally not sufficient to extract the bottom echo from data obtained over some portions of outlet glaciers. In areas with very rough ice surfaces and with an ice thickness between 500 and $700 \mathrm{~m}$,

This work is supported by NASA grant NAG5-8758. 
ice-bed interface returns are masked by off-vertical surface clutter and multiple echoes of the surface, as shown on the left-hand side of the radar echogram given in figure 1. Our goal is to determine the ice thickness in these outlet glacier areas by identifying the bottom echo using secondary processing techniques. We have applied signal conditioning and SAR processing to improve the signal to noise ratio by several $\mathrm{dB}$, but further signal processing is required. The methodology described here seeks to resolve the bottom echo near the calving front of outlet glaciers by modeling and removing the surface clutter caused by rough, crevassed glacier surfaces.

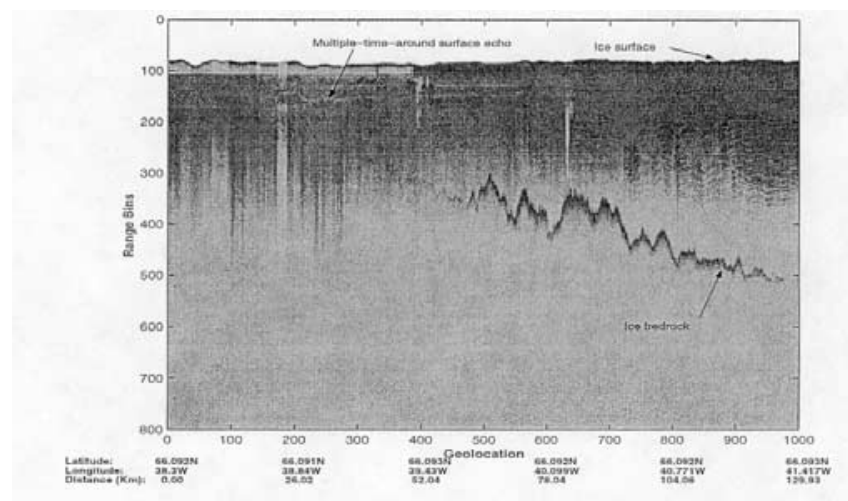

Fig. 1. Radar echogram illustrating the effect surface clutter on the ice-bedrock echo. Moving to the left on the echogram, the bottom echo is lost due to surface clutter.

\section{CLUTTER REDUCTION}

In order to identify the ice-bed interface obscured by surface clutter, we are in the process of developing a technique that first characterizes surface roughness using high precision laser altimetry data, then calculates a surface clutter waveform using a backscatter model. This modeled surface clutter waveform is then subtracted from the measured radar data. We are focusing our efforts on three Greenland outlet glaciers (Jakobshavn Isbrae, Kangerdlussnaq Glacier, and Helheim Glacier) for which ice thickness has not been fully characterized, which in part is due to surface clutter from rough, crevassed surfaces.

Surface roughness is characterized in terms of the standard deviation of the surface elevation, and the surface correlation length. For locations along the flight path with corresponding radar depth sounder measurements, the surface roughness parameters may be calculated using a dense array of highresolution, geo-located laser altimeter measurements of ice sheet elevation. The laser altimeter has a conical-scanning pattern and measures ice surface elevation over a $140 \mathrm{~m}$ swath along the flight path. The laser altimeter operates at a pulse rate of $2000 \mathrm{~Hz}$ and illuminates a surface footprint of about $1 \mathrm{~m}$ diameter. Precise ice surface elevation within each footprint is based on aircraft location determined by kinematic Global Positioning System (GPS) techniques [3]. Individual measurements have a root-mean-square elevation accuracy of $0.10 \mathrm{~m}$.

The procedure for obtaining the surface roughness parameters involves use of the Generic Mapping Tool (GMT) software [7] to map the large number of individual elevation measurements to an area of the outlet glacier surface along the flight path. These geo-located measurements are then used to generate an interpolated gridded elevation surface domain with grid dimensions $1 \mathrm{~m}^{2}$. The resulting highresolution gridded domain is then used to obtain a spatial elevation series along linear segments of the domain. The elevation series is detrended to remove the overall surface slope, and the detrended series of elevation is used to calculate the necessary roughness parameters.

Work is currently in progress on the development of the clutter reduction algorithm to calculate surface clutter waveforms. This algorithm will use the surface roughness parameters derived from laser altimeter measurements. Our conference poster will describe the clutter reduction algorithm and present the results obtained by applying this algorithm to radar data in the vicinity of the outlet glaciers Jakobshavn Isbrae and Helheim Glacier.

\section{REFERENCES}

[1] S. Gogineni, T. Chuah, C. Allen, K. Jezek, and R.K. Moore, "An improved coherent radar depth sounder," $J$. Glaciology, vol. 44, pp. 659-669, 1998.

[2] S. Gogineni, D. Tammana, D. Braaten, C. Leuschen, T. Akins, J. Legarsky, P. Kanagaratnam, J. Stiles, C. Allen, and K. Jezek, "Coherent radar ice thickness measurements over the Greenland ice sheet," J. Geophys. Res., vol. 106, pp. 33761-33772, 2001.

[3] W. Krabill, R. Thomas, C. Martin, R. Swift, and E. Fredrick, "Accuracy of laser altimetry over Greenland Ice Sheet," Int. J. Remote Sensing, vol. 16, pp. 12111222, 1995.

[4] W. Paterson, The Physics of Glaciers, $3^{\text {rd }}$ ed., Pergamon, 1994.

[5] W. Krabill, W. Abdalati, E. Frederick, S. Manizade, C. Martin, J. Sonntag, R. Swift, R. Thomas, W. Wright, and J. Yungel, "Greenland ice sheet: High-elevation balance and peripheral thinning," Science, vol. 289, pp. 428-430, 2000.

[6] N. Reeh, C. Mayer, H. Miller, H. Thomsen, and A. Weidick, "Present and past climate record on fjord glaciations in Greenland: Implications for IRDdeposition in the sea," Geophys. Res. Lett., vol. 26, pp. 1039-1042, 1999.

[7] P. Wessel and W.H.F. Smith, "New, improved version of Generic Mapping Tools released," EOS Trans. Amer. Geophys. U., vol. 79, pp. 579, 1998. 